Tropical Journal of Pharmaceutical Research, December 2008; 7 (4): 1169-1177

(C) Pharmacotherapy Group

Faculty of Pharmacy, University of Benin

Benin City, 300001 Nigeria.

All rights reserved.

Research Article

Available online at http://www.tjpr.org

\title{
Aspects of microbial quality of some milk products in Abuja Nigeria
}

\section{J Okpalugo*, K Ibrahim, KS Izebe, US Inyang}

Department of Microbiology and Biotechnology. National Institute for Pharmaceutical Research and Development (NIPRD), P.M.B. 21, Idu Industrial Area, Abuja, Nigeria

\begin{abstract}
Purpose: To assess the microbiological quality of some milk products in Abuja, Nigeria capital city; and the resistance of isolates to some broad spectrum antibiotics.

Method: Three packs of different brands of yoghurt and pasteurized milk purchased from four different locations were assessed in duplicate. Isolates were identified using growth on agar and broth, Gram's reaction, colony morphology, biochemical tests results and criteria for disregarding negative cultures. Resistance of isolates from pasteurized milk was determined using the antibiotic sensitivity test (zones of inhibition).

Results: 33 bacterial and 12 fungal isolates belonging to 9 and 3 genera respectively were identified from the yoghurt samples. Presence of yeast was found to increase the microbial load of bacterial groups and decrease the load of live and active cultures which was absent in $33 \%$ of yoghurt samples. $27 \%$ of samples were heat-treated and contained no LAC. A total of 19 bacterial isolates belonging to 6 genera were identified from the pasteurized milk samples. Milk quality based on methylene blue decolourization time measurement revealed that $49 \%$ of the assessed samples were of excellent quality, $37 \%$ of good quality, $14 \%$ of fair quality, and $0 \%$ of poor quality. No milk sample was sterile. Among the three antibiotics tested for resistance on the isolated bacterial strains, three different resistance patterns were observed.

Conclusion: Our study shows that mesophilic yeast was the main cause of yoghurt spoilage. Sampled yoghurt is unlikely to make a vital input to LAC intake in Nigerian diets and poses some yet undefined risk. Visual inspection of packages, quality assessment of diary plants/vessels and packaging materials, dye reduction tests, refrigeration at all times, and resistance testing should be critically considered before the use of recommended antibiotics.
\end{abstract}

KEY WORDS: Pasteurized milk, Yoghurt, Live and active cultures (LAC), Dye reduction tests, Antibiotics, Spoilage organisms, Bacterial resistance pattern. 


\section{INTRODUCTION}

Milk is man's indispensable food from infancy to old age. Pasteurization used since the early 1900s (heating raw milk to $161^{\circ} \mathrm{F}$ for 15 minutes) is expected to remove microorganisms from milk ${ }^{1}$. The microbiology of pasteurized milk can be determined by dye reaction test. Methylene blue when added to milk which is incubated at $37^{\circ} \mathrm{C}$ will be chemically reduced if there is microbial activity in the milk but do not indicate anything about the kind of bacteria in the milk. The time it takes for the methylene blue to become colorless is the methylene blue reduction time (MBRT). Government regulations require that dye tests be run to ensure that pasteurization is properly done and these tests alone should not be used in grading of milk ${ }^{2}$. Inadequately pasteurized milk may contain microorganisms of special importance to man $^{3}$ which its presence or absence in milk products may reflects success or failure of Good Manufacturing Practices (GMP) or cause infection when consumed together with food. This is of economic significance in Africa where the HIV/AIDS and cancer scourge has left the public who consume milk products immunosuppressed and prone to bacterial and fungal infection ${ }^{4}$.

Health complications associated with consumption of inadequately pasteurized milk products include serious infections that are hard to treat with antibiotics. This becomes clinically significant if organisms isolated from an assessed sample is resistant to conventional antibiotics, thus, can confer antibiotic resistance to the infected host while providing no alternative drug $^{5}$.

Under the standard of identity established by the U.S. Food and Drug Administration (FDA), in order for a refrigerated product to be called "yoghurt," it must be produced by culturing permitted dairy ingredients with a bacterial culture, which contains Lactobacillus bulgaricus and Streptococcus thermophilus (Live and Active Cultures, LAC) that convert milk to yoghurt during fermentation ${ }^{6}$. Heat treated yoghurt do not contain LAC as these are killed during post-fermentation heating. Yoghurt manufacturing companies may market "heat-treated yoghurt" to prolong yoghurt shelf life. LAC may help the body restore and maintain its normal balance of helpful bacteria, avert lactose intolerance, Gl infections, diarrhea and vaginal infection, osteoporosis, cancer, immunosuppression, lower cholesterol, folate supplementation ${ }^{7-9}$, and stop disease causing bacteria and yeast from growing ${ }^{10}$. Research backed by the International Association for Dental Research seems to show that eating plain live yoghurt for six weeks can reduce levels of oral bacteria by up to $80 \%$ so yoghurt is a traditional bad breath cure.

The National Yoghurt Association (NYA) established its own criteria for LAC in yoghurt in conjunction with its Live \& Active Culture seal program. For manufacturers to carry the seal, refrigerated yoghurt products must contain at least 100 million cultures per gram at the time of manufacture, and frozen yoghurt products must contain 10 million cultures per gram at the time of manufacture ${ }^{6}$. This level was based on a survey of leading research scientists involved in clinical studies of the health attributes associated with LAC yoghurt. Consumers can be certain they are getting yoghurt with significant levels of LAC by looking for the National Yoghurt Association (NYA) Live \& Active Cultures Yoghurt seal on the package in countries where this is obtainable. A decrease in the normal LAC counts may result in increase in yeast counts and development of bactericidal compounds 11,12 . Therefore, the importance of evaluating the aspects of microbial quality of some milk products in Abuja cannot be overemphasized.

\section{MATERIALS AND METHODS Sampling}

The study was conducted in Abuja, Nigeria's Federal Capital. Three packs each of yoghurt and pasteurized milk with different batch numbers, dates of manufacture and expiry were purchased from retail outlets in the metropolis at four different locations. Fifteen brands of yoghurt and thirteen brands of pasteurized milk were analyzed. All samples were collected using sterile polythene bags and analyzed at varying times throughout their 
Table 1: Total count (CFU/ml) and type of organism in milk products

\begin{tabular}{|c|c|c|c|c|c|c|c|c|c|}
\hline $\begin{array}{l}\text { Milk } \\
\text { Products } \\
\text { Number }\end{array}$ & $\begin{array}{l}\text { Lactic acid } \\
\text { bacteria }\end{array}$ & $\begin{array}{l}\text { Strepto- } \\
\text { coccus }\end{array}$ & $\begin{array}{l}\text { Entero- } \\
\text { coccus }\end{array}$ & $\begin{array}{l}\text { S. } \\
\text { aureus }\end{array}$ & Klebsiella & $\begin{array}{l}\text { E. } \\
\text { coli }\end{array}$ & Pseudomonas & $\begin{array}{l}\text { Salmone } \\
\text { lla }\end{array}$ & $\begin{array}{l}\text { Lactoco } \\
\text { cci }\end{array}$ \\
\hline $\mathrm{Y} 1$ & $+(800)$ & $+(80)$ & - & - & - & - & - & - & - \\
\hline Y2 & $+(900)$ & $+(12)$ & - & $+(3300)$ & - & $\stackrel{+}{(40)}$ & - & - & - \\
\hline Y3 & $+(400)$ & $+(420)$ & $\begin{array}{l}+ \\
(1000)\end{array}$ & - & - & $\begin{array}{l}+ \\
(12)\end{array}$ & - & - & - \\
\hline Y4 & - & - & - & - & - & - & - & - & - \\
\hline Y5 & - & - & - & - & - & - & - & - & - \\
\hline Y6 & - & - & - & - & - & - & - & - & - \\
\hline Y7 & $+(300)$ & $+(8900)$ & $\begin{array}{l}+ \\
(1800)\end{array}$ & $+(2500)$ & - & - & - & - & - \\
\hline Y8 & $+(1500)$ & $+(90)$ & - & - & $+(2200)$ & - & - & - & - \\
\hline Y9 & $+(2700)$ & $+(100)$ & - & - & - & - & - & - & - \\
\hline Y10 & $+(7000)$ & & - & - & - & - & - & - & - \\
\hline Y11 & - & - & - & - & - & - & - & - & - \\
\hline Y12 & $+(1900)$ & $+(6700)$ & - & - & - & $\begin{array}{l}+ \\
(47)\end{array}$ & - & - & - \\
\hline Y13 & $+(100)$ & $+(3300)$ & - & - & $+(1100)$ & - & - & - & - \\
\hline Y14 & $+(50)$ & - & $\begin{array}{l}+ \\
(1400)\end{array}$ & $+(1300)$ & - & $\begin{array}{l}+ \\
(21)\end{array}$ & - & - & - \\
\hline Y15 & $+(60000)$ & $+(7500)$ & - & - & - & - & - & - & - \\
\hline M1 & - & $+(200)$ & $+(3)$ & - & - & - & $+(92)$ & $+(80)$ & $+(200)$ \\
\hline M2 & $+(2)$ & - & - & - & - & - & - & - & - \\
\hline M3 & - & - & - & - & - & - & - & - & - \\
\hline M4 & - & $+(5200)$ & $+(140)$ & - & - & - & $+(520)$ & $+(54)$ & $\begin{array}{l}+ \\
(5200) \\
\end{array}$ \\
\hline M5 & $+(14)$ & - & - & - & - & - & - & - & - \\
\hline M6 & - & - & - & - & - & - & - & - & - \\
\hline M7 & - & $+(860)$ & $\stackrel{+}{(6400)}$ & - & - & - & - & - & $+(860)$ \\
\hline M8 & $+(230)$ & - & - & - & - & - & - & - & - \\
\hline M9 & - & - & - & - & - & - & - & - & - \\
\hline M10 & - & $+(3700)$ & - & - & - & - & $+(100)$ & - & $\begin{array}{l}+ \\
(3700)\end{array}$ \\
\hline M11 & $+(2900)$ & $+(400)$ & - & - & - & - & - & - & $+(400)$ \\
\hline M12 & - & - & - & - & - & - & - & - & - \\
\hline M13 & - & - & - & - & - & - & - & - & - \\
\hline
\end{tabular}

Absent (-); present (+); numbers in bracket = count of organism present in milk products.

Sample numbers with $Y$ and blanks (-) throughout were heat-treated yoghurt samples which contained yeast cells.

Sample numbers with $M$ and blanks throughout (-) were pasteurized milk not sterile but contained yeast cells. Because these yeast cells were not isolated and identified, such results were excluded from the work.

shelf life. Samples were analyzed individually, stored in the refrigerator and swabbed with $70 \%$ ethanol before opening. Culture media were rehydrated according to the manufacturer's instructions.

Isolation of microorganisms from milk products

Bacteria

Methylene blue reduction test is done to detect pasteurized milk samples containing bacteria. Ten fold serial dilutions of samples were made up to $10^{-6}$ in Nutrient broth (Becton Dickinson Ltd, USA, BBL $\left.{ }^{\circledR}\right)$ and Mac Conkey broth (Fluka Biochemika, Spain). Samples were plated in duplicate using pour plate technique. $0.5 \mathrm{ml}$ of the diluted samples was delivered by pipette into $19.5 \mathrm{ml}$ of enriched agar. Plates were incubated inverted in an incubator at $37 \circ \mathrm{C}$ for $24-48 \mathrm{~h}$. Total viable counts (aerobic mesophiles) were carried out on nutrient agar (Fluka Biochemika, Spain), Plate count agar (Oxoid, England), and 
Trypticase soy agar, Soybean casein digest agar (Becton Dickinson Ltd, USA). The number of colony forming units (CFU) per milliliter were counted and recorded after the appropriate incubation periods on plates with a visible colony range of 20-150. Cooked Meat Broth (Oxoid, England) was used for growth of aerobes and anaerobes where necessary. Quantitative analysis for the presence or absence of specific microorganisms was done by plating on selective media. Salmonella colonies on mannitol salt agar (Becton Dickinson Ltd, USA) were purified on Mac Conkey agar or Salmonella shigella agar SS- agar (Fluka Biochemika India) enriched with Selenite F Broth (International Diagnostic Group Plc, UK). Coliform count was done on Mac Conkey agar and Eosin Methylene Blue agar (International Diagnostic Group Plc, UK). Counts were also made on mannitol salt agar (Baird Parker Medium, Merck, Germany) and cetrimide agar (Merck, Germany). Confirmatory biochemical and serological tests were performed on purified colonies. Carbohydrate studies and Indole test was done in peptone water (International Diagnostic Group PIc, UK).

\section{Yeast}

Ten fold serial dilutions of sample were made up to $10^{-6}$ in Sabouraud dextrose broth (Merck, Germany) and peptone water. Samples were plated in duplicate using pour plate technique on Sabouraud dextrose agar (Merck, Germany) and Plate count agar (Oxoid, UK) to which $100 \mu \mathrm{g} /$ plate of streptomycin + chloramphenicol was added. $1 \mathrm{ml}$ of the diluted samples was delivered by pipette onto $19 \mathrm{mls}$ of agar. Plates were incubated inverted in the refrigerator at $7^{\circ} \mathrm{C}$ for 14 days, for psychrotropic yeast count and in an incubator at $22^{\circ} \mathrm{C}$ for 5 days, for mesophilic yeast counts. Total viable counts (aerobic and anaerobic mesophilic yeast) were made. The number of colony forming units (CFU) per milliliter were counted and recorded after the appropriate incubation periods.

\section{Characterization of isolates from milk products}

At intervals, colonies on the incubated plates were picked and purified by repeated sub culturing done by streaking on the desired media with a sterile wire loop (the strategy consisted of picking 1 colony to represent every visibly different morphology on each plate. A maximum of 5 colonies were obtained per sample) which were examined microscopically for Gram's reaction and colony morphology (shape, color, texture, size) using $24 \mathrm{~h}$ old cultures. Motility and classical biochemical tests were performed. Appropriate positive and negative controls were used to make a distinction between positive and "false-positive" reactions.

\section{Identification of isolates from milk} products

Identification was based on growth on selective agar and broth, colony morphology, Gram's reaction, biochemical tests results and criteria for disregarding negative cultures. Results were analyzed using Cowan and Steel Manual, and other methods for the Identification of Medical Bacteria ${ }^{13-15}$.

\section{Antibiotic Sensitivity Test}

Identified isolates were cultured in duplicate in enriched nutrient agar (agar diffusion method) in the presence of $1 \mathrm{ml}$ of antibiotic: penicillin 5000units; penicillin 5000units + streptomycin BP (5mg); penicillin (5000units) + streptomycin $(5 \mathrm{mg})+$ neomycin $(10 \mathrm{mg})$ in $0.9 \% \mathrm{NaCl}$ Sigma-Aldrich Co. Ltd, UK. Antibiotics were reconstituted in water for injection by dissolving two $2 \mathrm{mg}$ of each powder in $100 \mathrm{ml}$ of water to form a $20 \mu \mathrm{g}$ solution of antibiotic(s).

Pour plates of the isolates were prepared by seeding nutrient agar plates with an $18 \mathrm{hr}-$ broth culture of test organism and $1 \mathrm{ml}$ of $20 \mu \mathrm{g}$ solution of antibiotic(s) were added to a well cut in the agar medium with an agar plate cup borer. A third plate of positive laboratory controls (Lactobacillus, Lactococcus, Pseudomonas, Salmonella, Streptococcus, and Enterococcus) was subject to the same test and conditions. After incubation of plates for $48 \mathrm{hr}$ at $37^{\circ} \mathrm{C}$, an inhibitory effect on the test organism and isolates from pasteurized 
milk were assessed based on 'zones of inhibition' which were measured and interpreted accordingly ${ }^{16}$. This was also done for corresponding laboratory isolates after which the patterns of resistance of bacterial isolates to antibiotics were recorded.

\section{Determination of MIC of penicillin and streptomycin}

The MICs of both antibiotics were determined using the paper disc method. Sterile paper discs were immersed into graded concentrations of the two antibiotics after which they were aseptically layered on agar plates previously seeded with an $18 \mathrm{hr}$-broth culture of the test organisms (isolates from pasteurized milk and corresponding laboratory strains). The lowest concentration of each antibiotic which inhibited growth was taken as the MIC after the plates were incubated for 24 hr at $37^{\circ} \mathrm{C}$.

\section{Statistical analysis}

The data obtained were analyzed using SPSS (Statistical Package for Social Sciences) 10.0 for Windows, an installable software that enables assessment of data using several statistical functions. Chi Test was also used to test for independence.

\section{RESULTS}

Counts of bacterial groups (CFU $/ \mathrm{ml})$ isolated from milk products are listed in Table 1. Gram's reaction revealed the following results for yoghurt samples: positive cocci (52\%), gram-positive rods $(28 \%)$, gram-negative rods $(18 \%)$, gram-variable rods $(8 \%)$, and for pasteurized milk samples: gram-positive cocci $(52 \%)$, gram-positive rods (14\%), gramnegative rods $(26 \%)$, and gram-variable rods $(8 \%)$. S. aureus counts recorded were for coagulase-positive and negative cultures. Counts shown are mean counts of bacteria in each sample (whether of different batch number, dates of manufacture and expiry) it was isolated from. Yeast was found to significantly $(p<0.05)$ increase the bacterial microbial load by $98 \%$ 7days prior to expiry of samples; decrease the load of starter cultures and shorten sample shelf life Table 2. Counts shown are mean counts of yeast in each yoghurt sample (whether of different batch number, dates of manufacture and expiry) it was isolated from. Pseudomonas detected in samples was fluorescent colonies.

Antibiotic resistance pattern among laboratory bacteria revealed that $33 \%$ of isolates (Pseudomonas spp. and Salmonella spp.) were resistant to penicillin. $7 \%$ of Pseudomonas spp. isolates were found to be resistant to both penicillin and streptomycin. No laboratory isolate was found to be resistant to penicillin, streptomycin and neomycin triple therapy.

\section{DISCUSSION}

A total of 33 bacterial and 12 fungal isolates belonging to 9 and 3 genera, respectively were identified from yoghurt samples: Klebsiella spp., Lactobacillus spp. (acidophilus), Streptococcus spp., Micrococcus spp., E. coli, Staphylococcus spp. (S. aureus,), Sacharomyces spp. (S. dairensis), and Debaryomyces spp. The presence of yeast was found to significantly $(P<0.05)$ increase the microbial load of bacterial groups and decrease the load of starter cultures. Not all yoghurt samples contained live and active cultures. LAC was absent in $33 \%$ of the samples which bore yoghurt label. $27 \%$ of samples were heattreated and contained no beneficial cultures. The mean $( \pm S D)$ total bacterial count of all the samples was $2.2 \times 10^{5} \mathrm{CFU} / \mathrm{ml}( \pm 412.8)$ with a range from $3.6 \times 10^{3}-9.2 \times 10^{5} \mathrm{CFU} / \mathrm{ml}$ which is below the accepted standard for the total LAC count $\left(10^{7}-10^{8} \mathrm{CFU} / \mathrm{ml}\right)$. The mean LAC in samples was estimated to be $1.13 \times$ $10^{3} \mathrm{CFU} / \mathrm{ml}( \pm$ 82.9) which is below the recommended dose of LAC in yoghurt (Table 1 ). This shows that all sampled yoghurt is unlikely to adequately supply LAC to consumers. This is very disturbing as the ancient traditions of using LAC in food, combined with recent knowledge of positive health effects caused by the ingestion of probiotics, suggests LAC as promising alternatives to chemical preservation (especially in foods like yoghurt) ${ }^{11,}{ }^{12}$.

There were considerable differences in the microbiological quality of batches of milk products assessed. This together with 
Okpalugo et al

Table 2: Effect of yeast count on microbiology of yoghurt samples

\begin{tabular}{lllllll}
\hline Yeast group & $\begin{array}{l}\text { Mean } \\
\text { (CFU/ml) on } \\
\text { sample } \\
\text { collection }\end{array}$ & $\begin{array}{l}\text { Mean } \\
\text { (CFU/ml) } \\
\text { 7days to } \\
\text { expiry }\end{array}$ & $\begin{array}{l}\text { Samples } \\
\text { containing } \\
\text { yeast }\end{array}$ & $\begin{array}{l}\text { Total } \\
\text { Bacterial } \\
\text { load } \\
\text { (CFU/ml) } \\
\text { on sample } \\
\text { collection }\end{array}$ & $\begin{array}{l}\text { Total } \\
\text { Bacterial } \\
\text { load } \\
\text { (CFU/ml) } \\
7 \text { days to } \\
\text { expiry }\end{array}$ & $\begin{array}{l}\text { \% } \\
\text { increase } \\
\text { in } \\
\text { bacterial } \\
\text { load of } \\
\text { samples }\end{array}$ \\
\hline $\begin{array}{l}\text { Mesophilic } \\
\text { yeast }\end{array}$ & $4.9 \times 10^{3}$ & $4.5 \times 10^{5}$ & 93 & $2.2 \times 10^{5}$ & $1.9 \times 10^{7}$ & 98 \\
$\begin{array}{l}\text { Psychrotropic } \\
\text { yeast }\end{array}$ & $2.6 \times 10^{1}$ & $1.4 \times 10^{2}$ & 67 & & & \\
\hline
\end{tabular}

Table 3: Hygienic standard of yoghurt samples

\begin{tabular}{llllll}
\hline $\begin{array}{l}\text { Microorganism } \\
\text { isolated }\end{array}$ & $\begin{array}{l}\text { Mean } \\
(\mathrm{CFU} / \mathrm{ml})\end{array}$ & $\mathrm{SD}$ & $\begin{array}{l}\% \\
\text { samples } \\
\text { containing } \\
\text { organism }\end{array}$ & $\begin{array}{l}\text { \% samples } \\
\text { that passed sample that } \\
\text { standard } \\
\text { counts for } \\
\text { bacteria }\end{array}$ & $\begin{array}{l}\text { \% sailed standard } \\
\text { counts for } \\
\text { bacteria }\end{array}$ \\
\hline $\begin{array}{l}\text { Total mesophilic } \\
\text { bacteria }\end{array}$ & $2.2 \times 10^{5}$ & $4.0 \times 10^{2}$ & 86 & 33 & 67 \\
Acidophilus & $1.1 \times 10^{3}$ & $8.0 \times 10^{2}$ & 84 & None & All \\
$\begin{array}{l}\text { Enterococcus } \\
\text { spp. }\end{array}$ & $4.2 \times 10^{3}$ & $1.3 \times 10^{2}$ & 39 & 61 & 39 \\
E. coli & $1.2 \times 10^{2}$ & $1.6 \times 10^{2}$ & 12 & 88 & 12 \\
S. aureus & $7.1 \times 10^{3}$ & $9.9 \times 10^{3}$. & 31 & 69 & 31 \\
Klebsiella spp. & $3.1 \times 10^{3}$ & $1.2 \times 10^{3}$ & 23 & 77 & 23 \\
\hline
\end{tabular}

isolation of indicator organisms shows failure of GMP in industries that manufactured milk products from which they were isolated ${ }^{17}$. E. coli being an index organism indicated the presence of other pathogenic organisms like Klebsiella and $S$. aureus. Amongst food poisoning organisms, $S$. aureus and $E$. coli were isolated. This could be due to water used in manufacture, unhygienic hawking habits, storage environment and not necessarily failure of GMP. S. aureus has been linked to gastroenteritis by producing enterotoxins, boils, skin infections, (pneumonia, deep abscesses and meningitis in debilitated persons). About $40 \%$ of isolated Staphylococcus was coagulase-positive. Because $S$. aureus is highly vulnerable to destruction by heat treatment and nearly all sanitizing agents, the presence of this bacterium or its enterotoxins in pasteurized yoghurt is an indication of poor sanitation or post pasteurization contamination. E. coli has been linked to diarrheal diseases, urethrocystitis, prostatitis, pyelonephritis. Klebsiella has been related to bacterial pneumonia cases more severe than those produced by $S$. pneumonia and UTIs (urinary tract infections).

Samples contained yeast which is a spoilage organism in yoghurt because of its ability to inhibit LAC, increase microbial load of harmful organisms and shorten shelf life. The mean $( \pm$ SD) psychrotropic and mesophilic yeast counts were $2.6 \times 10^{1}( \pm 3.93)$ and $4.9 \times 10^{3}$ 
Table 5: Quality of milk based on methylene blue decolourization time

\begin{tabular}{llll}
\hline $\begin{array}{l}\text { No. of } \\
\text { Samples }\end{array}$ & $\begin{array}{l}\text { Methylene Blue } \\
\text { Decolourization } \\
\text { Time (hours) }\end{array}$ & $\begin{array}{l}\text { \% Quantity of } \\
\text { Assessed } \\
\text { Milk Sample }\end{array}$ & $\begin{array}{l}\text { Quality/ Grade } \\
\text { of Milk }\end{array}$ \\
\hline & & & Excellent \\
7 & 2 & 54 & Good \\
4 & 4 & 31 & Fair \\
2 & 6 & 15 & Poor \\
0 & 8 & 0 & \\
\hline
\end{tabular}

Table 6: Antibiotic resistance pattern among pasteurized milk bacteria isolates

\begin{tabular}{lllll}
\hline $\begin{array}{l}\text { Number of } \\
\text { antibiotics }\end{array}$ & $\begin{array}{l}\text { Resistance } \\
\text { pattern }\end{array}$ & $\begin{array}{l}\text { No. of } \\
\text { isolates }\end{array}$ & Type of isolate & $\%$ \\
\hline 1 & Pen & 6 & $\begin{array}{l}\text { Ps, Strp, Entr, } \\
\text { Lactb, Lactc, } \\
\text { Salm }\end{array}$ & 59 \\
& Pen, Str & 4 & $\begin{array}{l}\text { Ps, Strp, Entr, } \\
\text { Lactc }\end{array}$ & 22 \\
2 & Pen, Str, Neo & 2 & Ps, Strp & 8 \\
3 & Penicillin; Str = streptomycin; Neo = Neomycin; Ps = Pseudomonas spp.; Strp = Streptococci spp.; Entr =
\end{tabular}

$( \pm 71.4) \quad$ CFU $/ \mathrm{ml}$ respectively. 7 days to the supposed expiry date, these mean counts increased to $1.4 \times 10^{2}$ and $4.5 \times 10^{5} \mathrm{CFU} / \mathrm{ml}$ for yeast and $1.9 \times 10^{7} \mathrm{CFU} / \mathrm{ml}$ for total bacterial load. Some guidelines have suggested that yeast counts should not exceed $10^{3} \mathrm{CFU} / \mathrm{g}$ or $\mathrm{ml}$ but most samples assessed had yeast counts $>10^{3} \mathrm{CFU} / \mathrm{ml} 7$ days to the supposed expiry date. Because most of the yeast isolated grew at $22{ }^{\circ} \mathrm{C}$, it could be concluded that mesophilic yeast were the main cause of spoilage and increased the bacterial load of samples by 98\% (Table 2). Certainly, the poor hygienic condition of some assessed samples (Table 3) could be linked to their initial bacteriological load, storage temperature, hygienic measures during processing, packaging and handling techniques ${ }^{18}$.

A total of 19 bacterial isolates belonging to 6 genera were identified from pasteurized milk samples: Lactobacillus, Lactococcus,
Pseudomonas, Salmonella, Streptococcus, and Enterococcus (Table 4). No milk product was sterile. This shows that pasteurization makes milk safer. It does not render it sterile. It also nullifies the concept of zero tolerance as some of the assessed milk samples imported from developed countries contained pathogens. Isolation of pathogenic bacteria from $38 \%$ of assessed samples revealed either post pasteurization contamination or improper pasteurization techniques as the major source of contamination. This is a source of concern as pathogenic bacteria have been known to trigger the outbreak of epidemics. Table 5 shows the quality of milk based on methylene blue decolourization time.

Among the three antibiotics tested for resistance on the isolated bacterial strains, two different resistance patterns were observed out of which one was multiple-drug resistance, with the number of antibiotics 
being two (Table 6). Most laboratory positive controls and isolates identified as Salmonella and Pseudomonas were resistant to penicillin. Some gram-positive isolates identified as Streptococcus, Enterococcus, Lactobacillusand Lactococcus were resistant to penicillin. Before the administration of penicillin, the total gram-negative viable count of isolates was $1.8 \times 10^{2} \mathrm{CFU} / \mathrm{ml}$ and contained $39 \%$ Salmonella and $47 \%$ Pseudomonas and total gram- positive viable count of $0.1 \times 10^{3} \mathrm{CFU} / \mathrm{ml}$ and contained $19 \%$ Lactobacilli, 35\% Streptococci, and 21\% Lactococci, 11\% Enterococci. After the administration of penicillin, the antibioticresistant microbial load increased from $1.8 \times$ $10^{2}-9.3 \times 10^{3} \mathrm{CFU} / \mathrm{ml}$ for gram-negative isolates and from $0.1 \times 10^{3}-4.0 \times 10^{4} \mathrm{CFU} / \mathrm{ml}$ for gram-positive isolates. The $8 \%$ of isolates resistant to the three different antibiotics were identified as Pseudomonas and Streptococci spp. Streptococcus spp. has been implicated in pharyngitis, tonsillitis, sinusitis, otitis, arthritis, bone infections, bacterial pneumonia, acute rheumatic fever, and glumerulonephritis. Resistance of some Streptococci spp. to penicillin which is the drug of choice for $S$. pyogenes and $S$. pneumonia and rheumatic fever prophylaxis (when the organism is susceptible) is clinically significant. Pseudomonas has been implicated in localized/generalized infections following surgery or burns, nosocomial infections e.g. UTIs following catheterization, eye and ear infections which may be serious in hospitalized patients or those with cancer consume pasteurized milk. Salmonella spp. has been implicated in gastroenteritis, enteric (typhoid) fever and septicemia. Since all, except gastroenteritis, should be treated with broad spectrum antibiotics like penicillin, this too is clinically significant.

Antibiotic resistance of isolated strains from milk products in Abuja may be a reflection of the harmful effects of self medication or inadequate medical indication by the health professionals. Many antibiotics are persistent in the environment and have been isolated from ground water ${ }^{19}$ which could be used at times in the preparation of milk products. As shown in the study, this could enhance the spread of bacterial resistance among people who may consume these products. The MICs $(\mu \mathrm{g} / \mathrm{ml})$ of penicillin against the strains of isolates was 18 and 14 for Klebsiella spp., 11 and 15 for Bacillus spp., and 18 and 16 for Enterococcus spp. The MICs of streptomycin against the strains of isolates was 10 and 11 for Klebsiella spp., 7 and 9 for Bacillus spp., and 14 and 17 for Enterococcus spp. Clearly, resistance of isolates to penicillin was higher than that seen in streptomycin. This may be due to the production of $\beta$-lactamase in by these bacterial isolates resistant to the $\beta$ lactam antibiotic ${ }^{20}$.

In view of these findings, the use of yeast free starter cultures, strict hygiene and packaging, avoiding heat treating of yoghurt, maintenance of an effective cold chain from production till consumption, LAC seal on yoghurt, provision of lab analysis certifying the levels of cultures in their products and shortening of shelf life to 14 days irrespective of preservative added, is recommended for yoghurt manufacturers. Consumption of yoghurt within 14 days of production irrespective of its shelf life and refrigeration at all times is recommended for yoghurt consumers. Assessment of "GMP" of milk manufacturing industries and lab analysis certifying the levels of cultures in their products, shortening of shelf life of yoghurt to 14 days irrespective of the preservative added, and LAC seal on yoghurt is recommended for the Nigerian Quality Control System. This is because the seal enables consumers to make informed choices when they buy yoghurt and assures them they are getting a certain level of LAC they may or may not desire. Visual inspection of packages, quality assessment of dairy plants/vessels and packaging materials, dye reduction tests, refrigeration at all times, and resistance testing should be critically considered before use of recommended antibiotics.

\section{CONCLUSION}

Evaluated milk products clearly pose some yet undefined risks. This is of clinical significance in immunosuppressed people who may consume these products. These groups of 
people should be cautious when consuming milk products as they may eat isolates resistant to some broad spectrum antibiotics. This is because the concentration of bacteria in milk products varies widely from one manufacturer to another and lack of standardization makes it hard to be sure of the quality. The relatively high level of resistance to antimicrobial agents constitutes a major threat to public health as it may spread bacterial resistance among the populace who come in contact with milk products. Since public perception of food quality is critical in the marketing of any product, it is very important that the Nigerian milk products industry maintains high processing standards.

\section{ACKNOWLEDGEMENT}

We acknowledge the selfless support of all the technical staff and IT students at NIPRD Microbiology Laboratory during the period of the study. The authors wish to thank Mr. Emeje Martins and Mr. Femi for their thoughtful suggestions.

\section{REFERENCES}

1. Imele H., Kamage A., Mendi S. Effect of pasteurization temperature on the total milk flora. Bull. Ani. Health and Production in Africa 2002; 48 (3): 177-181.3

2. [USFDA] U.S. Food and Drug Administration. Grade " $A$ " pasteurized milk ordinance. Washington, D.C.: U.S. Dept. of Health and Human Services Public Health Service. 2001; pp 290

3. Boor KJ, Murphy SC. Microbiology of market milks: In Dairy microbiology handbook: the microbiology of milk and milk products. Robinson, RK, editor New York: WileyInterscience. $3^{\text {rd }}$ ed. 2002; pp 91-122.

4. Boor KJ. Fluid dairy product quality and safety: looking to the future. J. Dairy Sci. 2001; 84:111.5

5. Gould IM. Risk factors for acquisition of multiply drug-resistant Gram-negative bacteria. Eur. J. Clin. Microb. Inf. Dis. 1994; 13: 30-8

6. About Yoghurt Com. National Yoghurt Association (NYA). www.aboutyoghurt.com Accessed 6 July, 2007.

7. De-Roos NM, Katan MB. Effects of probiotic bacteria on diarrhea, lipid metabolism, and carcinogenesis. A review of papers published between 1988 and 1998. Am. J. Clin. Nutr.
2000; 71: 405-411.

8. Hove $H$, Norgaard $H$, Mortensen, PB. Lactic acid bacteria and the human gastrointestinal tract. Eur. J. Clin. Nut. 1999; 53: 339-350.

9. Ishiakawa H, Akedo I, Otani, T. Randomized trial of dietary fiber and Lactobacillus casei administration for preservation of colorectal tumors. Int. J. Cancer. 2005; 116: 762-767.

10. Magnusson J, Strom K, Roos S, Sjogren J, Schurer $J$. Broad and complex antifungal activity among environmental isolates of lactic acid bacteria, FEMS Microb. Letters 2003; 219: 129-135.

11. Viljoen, BC. The interaction between yeasts and bacteria in diary environments, Int. J. Food Microb. 2001; 69: 37-44.

12. Davidson, MP. Chemical preservatives and natural antimicrobial compounds. In: Food Microb. Fundamentals and Frontiers, ASM Press, Washington 2001; pp. 593-627.

13. Barrow GI, Feltham KA. Cowan and Steel Manual for the Identification of Medical Bacteria. $3^{\text {rd }}$ ed., Cambridge. 1993.

14. Da Silva ZN, Cunha AS, Lins MC, Carneiro L, Almeida AC, Queuro ML. Isolation and serological identification of enteropathogenic Escherichia coli in pasteurized milk in Brazil. Rev. Saude publica 2001; 35 (4): 375-379.

15. Ellis DI, Goodacre R. Detection, identification, and enumeration methods for spoilage yeasts, $p$. 28-54In Blackburn C deW (ed.), Food Spoilage organisms. CRC Press LLC. 2006.

16. Oloke JK. 'Activity pattern of natural and synthetic antibacterial agents among hospital isolates.' Microbios. 2000; 102, 175-181.

17. Risk Management and Food Safety. Report of a joint FAO/WHO Expert Consultation, Rome, Italy, 1997. FAO Food and Nutr. Paper No 65.

18. Gruetzmacher TJ, Bradley RL. Identification and control of processing variables that affect the quality and safety of fluid milk. J. Food Prot. 1999; 62: 625-31.

19. Thurman EM, Hostetler KA. 'Analysis of tetracycline and sulfamethazine antibiotics in groundwater and animal-feedlot wasteland by high performance liquid chromatography/mass spectrometry using positive-ion electrosray. Effects of animal feeding operations on water resources and the environment,' Proceedings of the Technical Meeting, Fort Collins, CO, 30 August-1 September 1999, Abstract, p.47. Zuccato E, Calamar D, Natangelo $M$, Fanelli $R$. 'Presence of therapeutic drugs in the environment.' Lancet 2000; 355, 1789-1790

20. Khan RMK, Malik $A$. 'Antibiotic resistance and detection of $\beta$-lactamase in bacterial strains of Staphylococci and E. coli isolated from foodstuffs.' World J. Microb. Biotech. 2001; 17, 863-868. 